\title{
EFFECTS OF PROCESSING PARAMETERS ON THE MICROSTRUCTURE AND MECHANICAL PROPERTIES OF Al-Si-Cu ALLOY AFTER VACUUM SUCTION CASTING
}

\author{
VPLIV PROCESNIH PARAMETROV NA MIKROSTRUKTURO IN \\ MEHANSKE LASTNOSTI ZLITINE Al-Si-Cu PO VAKUUMSKEM \\ SESALNEM LITJU
}

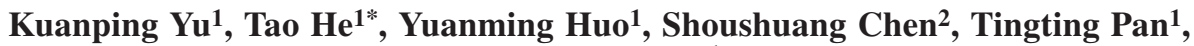 \\ Xingqian Dong 1 \\ ${ }^{1}$ School of Mechanical and Automotive Engineering, Shanghai University of Engineering Science, Shanghai 201620, China \\ ${ }^{2}$ Chinese Academy of Social Sciences, Institute of Quantitative and Technical Economics, 5 Jianguomennei Street, Beijing 100732, China
}

Prejem rokopisa - received: 2019-01-22; sprejem za objavo - accepted for publication: 2019-03-27

doi:10.17222/mit.2019.020

\begin{abstract}
High performance of complex thin-walled parts based on bottom-hole vacuum suction casting (VSC) has drawn considerable research interest. Here, we report on the preparation of $\mathrm{Al}-7 \mathrm{Si}-4.5 \mathrm{Cu}-0.15 \mathrm{Mg}-0.1 \mathrm{Ti}$ alloy castings with the use of different VSC processing parameters. The microstructure and mechanical properties of the castings were analyzed with scanning electron microscope imaging, a universal tensile tester and a microhardness tester. Our experimental results showed that the microstructure of the castings was relatively compact. When the negative differential pressure increased, the number of primary Si flakes decreased and the distribution of the $\alpha(\mathrm{Al})+\mathrm{Si}$ eutectic became more uniform and better oriented. Apparent shrinkage and looseness of the morphology also decreased. When the suction diameter was decreased, the apparent microporosity decreased at first and then increased. The distribution of the eutectic Si flakes became more uniform at first and then more chaotic. A suction diameter of $3 \mathrm{~mm}$ and negative differential pressure of $0.08 \mathrm{MPa}$ gave the best mechanical properties, namely a tensile strength of 195.8 MPa, elongation at break of $14.093 \%$ and microhardness of $107.3 \mathrm{HV}$.
\end{abstract}

Keywords: vacuum suction casting, processing parameter, microstructure, mechanical properties

V zadnjem času se je povečal interes za raziskave izdelave kakovostnih kompleksnih izdelkov s tankimi stenami, ki so izdelani z vakuumskim sesalnim litjem (VSC; angl.: Vacuum Suction Casting) z odprtino na dnu. Avtorji poročajo o pripravi zlitine Al-7Si-4,5 Cu-0,15Mg-0,1Ti, izdelane pri različnih procesnih parametrih VSC. Mikrostrukturo zlitin so analizirali pod vrstičnim elektronskim mikroskopom (SEM), mehanske lastnosti pa so določili na univerzalnem trgalnem stroju. Mikrotrdoto zlitin so določili z Vickersovim merilnikom trdote. Rezultati analiz so pokazali, da so izdelane zlitine relativno kompaktne. Z naraščajočim negativnim delnim tlakom se je zmanjševalo število primarnih Si ploščic ter porazdelitev evtektika $\alpha(\mathrm{Al})+\mathrm{Si}$ je postajala enovitejša in bolj orientirana. Navidezni skrček in nenatančnost sta se prav tako zmanjšala. Ko so zmanjševali premer sesalne odprtine, se je najprej zmanjševala, nato pa začela povečevati navidezna mikroporoznost. Porazdelitev Si ploščic je temu primerno najprej postajala bolj enovita in nato bolj kaotična. Pri $3 \mathrm{~mm}$ premeru sesalne odprtine na dnu in negativnem delnem tlaku 0,08 $\mathrm{MPa}$, so dobili najboljše mehanske lastnosti zlitine, in te so natezna trdnost 195,8 MPa, raztezek pri prelomu $14,093 \%$, in mikrotrdota 107,3 HV.

Ključne besede: vakuumsko sesalno litje, procesni parametri, mikrostruktura, mehanske lastnosti

\section{INTRODUCTION}

Owing to their good ductility, processability, toughness and moderate strength, Al-Si-Cu multiphase alloys have been widely used in manufacturing complex thin-walled parts, such as automobile engine cylinder blocks, aeronautical compressor impeller blades and other aircraft parts. ${ }^{1-4}$ At present, thin-walled parts are mainly processed using numerically controlled machining and gypsum die-casting, pressure casting, and anti-gravity vacuum suction casting. 5,6 Yanqing and others proposed bottom-hole VSC, based on anti-gravity VSC. This technology allows a copper mold to be filled with liquid metal through the combined action of gravity and negative pressure. Therefore, these methods are suit-

*Corresponding author's e-mail

hetao@sues.edu.cn able for forming complex thin-walled parts. Additionally, this processing makes the casting structures compact while the mechanical properties are improved. Thus, bottom-hole VSC has become more popular among researchers. ${ }^{7,8}$

Numerous articles on bottom-hole VSC were published. Yanqing et al. prepared a titanium-alloy impeller with the use of bottom-hole VSC and studied the influence of process parameters on the melt fluidity. ${ }^{9}$ Xicong prepared titanium-alloy blades with bottom-hole VSC. ${ }^{10}$ His experimental results showed that the average grain size of the blades was less than $20 \mu \mathrm{m}$ and the mechanical properties of the blades were excellent. Samal studied the phase evolution and mechanical behavior of a Ti-Fe-Co alloy obtained with vacuum suction casting. ${ }^{11}$ Das studied the microstructure of a $\mathrm{Zr}-16$ w/\% SS alloy prepared with VSC and found that the corrosion resis- 
tance of the alloy also improved as a result of an increase in the phase distribution of $\mathrm{Zr}(\mathrm{Fe}, \mathrm{Cr}) .{ }^{12}$ Ito et al. studied the effects of the cooling rate and melt temperature on the microstructure and mechanical properties of subs prepared with VSC. Their results showed that a set of reasonable processing parameters could be selected to reduce the formation of voids and the shrinkage. ${ }^{13}$ Kashiwai studied the mold-filling process of VSC using numerical simulations and X-ray observations. These results show that the effectiveness of mold filling depends on the proper processing parameters. ${ }^{14}$ Today, there have been few reports on $\mathrm{Al}-\mathrm{Si}-\mathrm{Cu}$ alloys prepared with bottom-hole VSC. ${ }^{15}$ Furthermore, there is a lack of reasonable processing parameters improving the mechanical properties of $\mathrm{Al}-\mathrm{Si}-\mathrm{Cu}$ alloys.

The aim of this work is to study the effects of processing parameters on the microstructure and mechanical properties of $\mathrm{Al}-\mathrm{Si}-\mathrm{Cu}$ alloy castings prepared with VSC to optimize the VSC processing window and achieve high performance. First, we prepared Al-7Si-4.5Cu-0.15Mg-0.1Ti alloy castings using suction holes of different diameters and negative differential pressures. Second, we observed the microstructure and properties of the cast specimens. Third, we examined the effects of processing parameters on the microstructure and mechanical properties of the $\mathrm{Al}-\mathrm{Si}-\mathrm{Cu}$ alloy castings.

\section{MATERIALS AND METHODS}

\subsection{Specimens prepared with bottom-hole VSC}

The chemical composition of the Al-Si-Cu alloy is shown in Table 1. A schematic diagram of the experimental equipment is shown in Figure 1. The experimental steps of vacuum suction casting were as follows: 1) The experimental materials were prepared according to the proportions listed in Table 1. The purity of the raw materials was $99.99 \%$. 2) The materials were melted in an argon-protected melting chamber. After 2-4 cycles of melting and solidifying, the mixture was smelted into an

alloy ingot with a smooth surface. Then, magnetic stirring was switched on and the sample was melted further for 2-3 times until the composition of the alloy ingot became uniform. Magnetic stirring of the molten alloy was performed under non-contact conditions, improving the uniformity of the composition of the alloy ingot. 3) The alloy ingot was moved to a suction crucible with a mechanical claw and melted into a liquid with the suction valve being open. Then the alloy liquid was passed into the copper mold in the suction chamber through a graphite suction hole under the combined action of gravity and the negative-pressure differential between the suction chamber and the melting chamber. The mold became completely filled. 4) The alloy liquid was then cooled and solidified in the copper mold under a vacuum and low pressure. Finally, specimens of $\phi 10 \times 80 \mathrm{~mm}$ were obtained.

Table 1: Chemical composition of Al-Si-Cu alloy (w/\%)

\begin{tabular}{|c|c|c|c|c|c|}
\hline $\mathrm{Si}$ & $\mathrm{Cu}$ & $\mathrm{Mg}$ & $\mathrm{Ti}$ & Impurity & $\mathrm{Al}$ \\
\hline 7.0 & 4.5 & 0.15 & 0.1 & $=0.01$ & $\mathrm{Bal}$. \\
\hline
\end{tabular}

The main processing parameters of the bottom-hole VSC are the pouring temperature, suction diameter and negative differential pressure. It is difficult to control the pouring temperature of VSC; hence, in this study, we focused on the influence of the suction diameter and negative differential pressure on the microstructure and the resulting mechanical properties. Details of the tested parameters are listed in Table 2.

Table 2: Experimental processing parameters

\begin{tabular}{|c|c|c|}
\hline $\begin{array}{c}\text { Experiment } \\
\text { number }\end{array}$ & $\begin{array}{c}\text { Diameter of the suc- } \\
\text { tion hole } / \mathrm{mm}\end{array}$ & $\begin{array}{c}\text { Negative differential } \\
\text { pressure } / \mathrm{MPa}\end{array}$ \\
\hline 1 & 2.5 & 0.05 \\
\hline 2 & 3 & 0.02 \\
\hline 3 & 3 & 0.05 \\
\hline 4 & 3 & 0.08 \\
\hline 5 & 3.5 & 0.05 \\
\hline
\end{tabular}

(a)

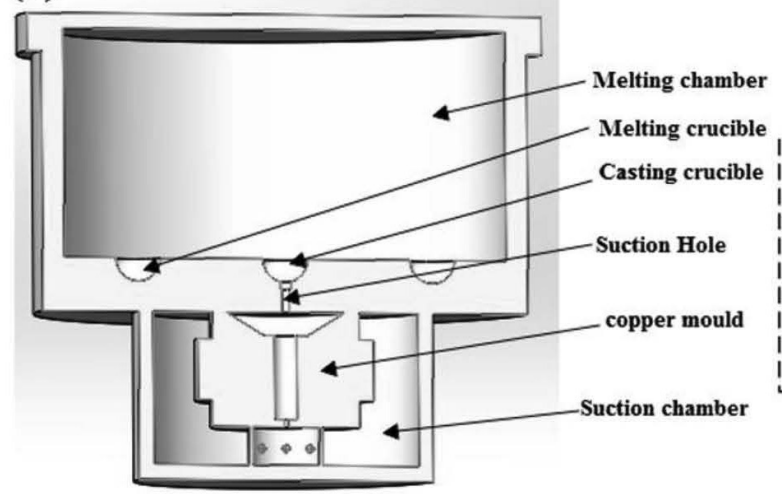

(b)

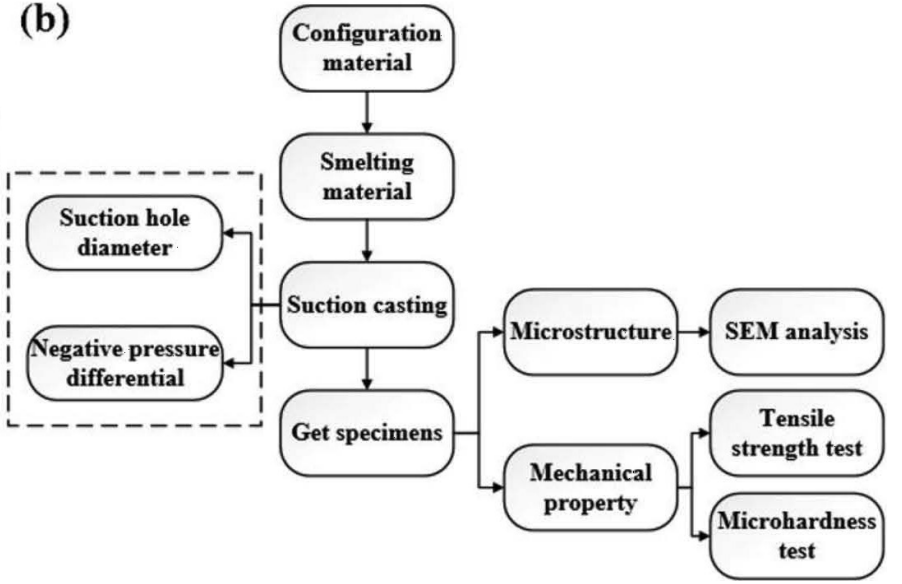

Figure 1: Schematic diagrams of the experiments: a) schematic of bottom-hole vacuum suction casting, b) flowchart of the experiment 
The $\phi 10 \times 80 \mathrm{~mm}$ specimens prepared with VSC were held at $515{ }^{\circ} \mathrm{C}$ for $6 \mathrm{~h}$ in an SX2 series box resistance furnace and then quenched with water at $50{ }^{\circ} \mathrm{C}$. Solution ageing was performed at $175^{\circ} \mathrm{C}$ for $5 \mathrm{~h}$, and then air cooled at room temperature.

\subsection{Microstructural observations of the specimens}

The as-cast specimens were observed using scanning-electron-microscope (SEM) imaging. The observed specimens were machined from the as-cast specimens. The samples were sequentially roughly and finely ground with water abrasive paper of grades of 800, 1200, 1500, and 2000. An MP-2B double-disk variable speedgrinding machine was used to polish the sectioned surfaces. The polished surfaces were etched with a $0.5 \%$ HF acid alcohol solution for $20 \mathrm{~s}$, then washed with clean water and alcohol and quickly dried. Finally, the microstructure of the specimens was observed and analyzed with a Hitachi SU8070 SEM.

\subsection{Testing mechanical properties of the specimens}

The hardness of the polished samples was tested at five points, each measured five times. After removing the maximum and minimum values, the average value was taken as the Vickers hardness.

The next step was to test the microhardness and tension strength with an MHVD-1000IS multifunction image microhardness instrument and a universal testing machine, respectively. The $\phi 10 \times 15 \mathrm{~mm}$ hardness specimens and tension specimens were also machined from the as-cast material using a DK7632 slow-walking wire-cutting machine. To prevent the influence of scratches or cracks caused by wire cutting, coarse and fine grinding of the tension specimens were performed with abrasive paper of grades of 800 and 1500 . Then the tensile strength and elongation at break were measured at a tensional speed of $1 \mathrm{~mm} / \mathrm{min}$. The tensile specimen and tensile-failure specimens are shown in Figure 2. Tensile

(a)
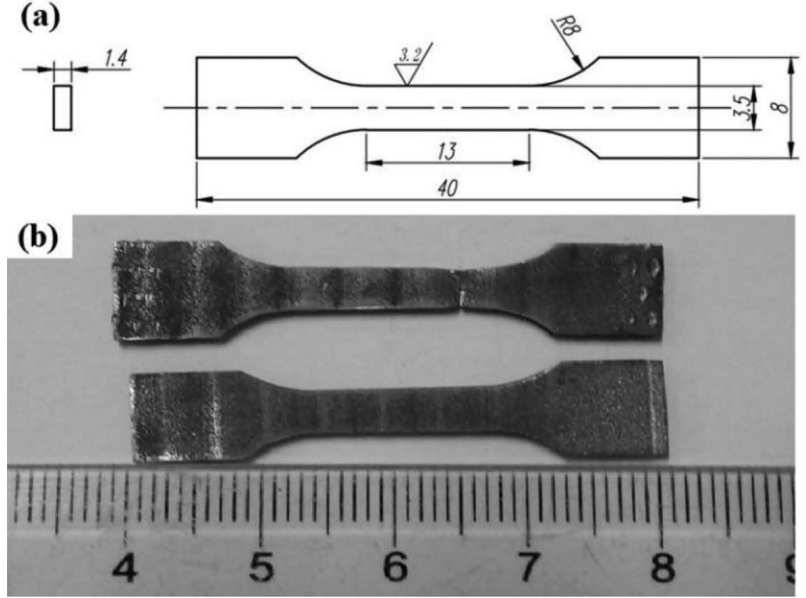

Figure 2: Tensile specimen: a) size of tensile specimen, b) tensile-specimen fracture tests were conducted following the ASTM E8M Standard.

\section{RESULTS AND DISCUSSION}

\subsection{Effects of the suction diameter on the microstruc- ture}

Figures 3, 4 and $\mathbf{5}$ show the microstructure and EDS analysis results for the castings made under a negative differential pressure of $0.05 \mathrm{MPa}$ and at suction diameters of $(2.5,3$ and 3.5$) \mathrm{mm}$, respectively. A detailed description of the microstructure of the Al-Si-Cu alloy is shown in Table 3. ${ }^{16,17}$ There is one-to-one correspondence between Figures 3, 4 and $\mathbf{5}$ and Table 3 for the phase composition. Table 4 shows mass fractions of the elements for each EDS test point from Figures 3, 4 and 5.

Table 3: Main phases and morphologies of the microstructure of the Al-Si-Cu alloy

\begin{tabular}{|c|c|c|}
\hline $\begin{array}{c}\text { Serial } \\
\text { number }\end{array}$ & $\begin{array}{c}\text { microstructure mor- } \\
\text { phology }\end{array}$ & phase composition \\
\hline 1 & skeletal shape & $\alpha(\mathrm{Al})$ matrix \\
\hline 2 & strip shape & $\alpha(\mathrm{Al}) £$ « Si eutectic \\
\hline 3 & polygonal flake & primary Si \\
\hline 4 & bright white flake & $\theta\left(\mathrm{Al}_{2} \mathrm{Cu}\right)$ \\
\hline 5 & black pore & microporosity \\
\hline 6 & black granular & insoluble impurity phase \\
\hline
\end{tabular}

The microstructure of the casting was relatively compact and the grain size was small owing to a rapid cooling of the metal mold (Figure 3). However, all the castings had microporous defects because of a rapid condensation rate. These features degrade the mechanical properties of castings. ${ }^{18}$ The diameter of the suction port greatly influenced the microporosity of the castings. When the suction diameter was $2.5 \mathrm{~mm}$, the microporosity was high and widely distributed, as shown in Figure 3. For the sample formed at a hole size of $3.5 \mathrm{~mm}$, although the number of microvoids decreased, larger holes formed through the local aggregation, as shown in Figure 5. When the suction diameter was 3 $\mathrm{mm}$, the pores were the smallest and the least numerous, as shown in Figure 4, and the quantity of the lamellar $\alpha(\mathrm{Al})+\mathrm{Si}$ eutectic in the matrix was small. We attribute this result to the polygonal flakes of primary Si dissolved in the $\alpha(\mathrm{Al})$ matrix, which then became eutectic Si. For suction diameters of $2.5 \mathrm{~mm}$ and $3.5 \mathrm{~mm}$, the number of primary flakes of Si was higher.

Additionally, more dark bulk microporous and granular insoluble impurity phases were inhomogeneously scattered in the matrix (Figure 3). These particles markedly affected the continuity of the $\alpha(\mathrm{Al})$ matrix, which might have weakened the mechanical properties and corrosion resistance of the castings. ${ }^{19}$ In addition, the polygonal primary Si flakes were also more abundant, owing to their insolubility in the $\alpha(\mathrm{Al})$ matrix and distribution 
K. YU et al: EFFECTS OF PROCESSING PARAMETERS ON THE MICROSTRUCTURE AND MECHANICAL PROPERTIES ...
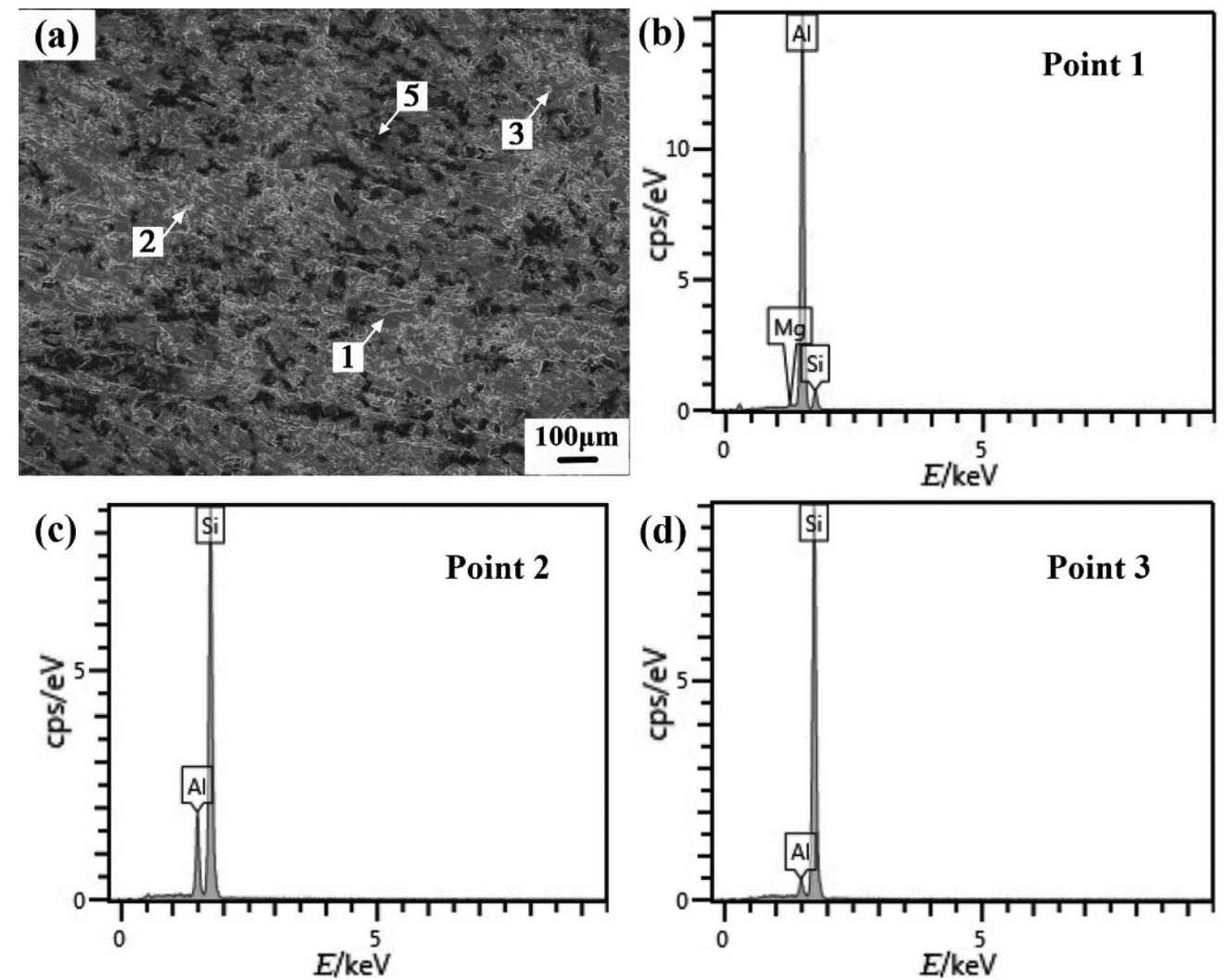

Figure 3: Microstructure with a suction diameter of $2.5 \mathrm{~mm}$ and EDS results: a) microstructure: 1 - (Al) matrix, 2 - eutectic Si, 3 - primary $\mathrm{Si}, 5$ - microporous area, b) (Al) matrix, c) (Al) + Si eutectic structure, d) primary Si phase
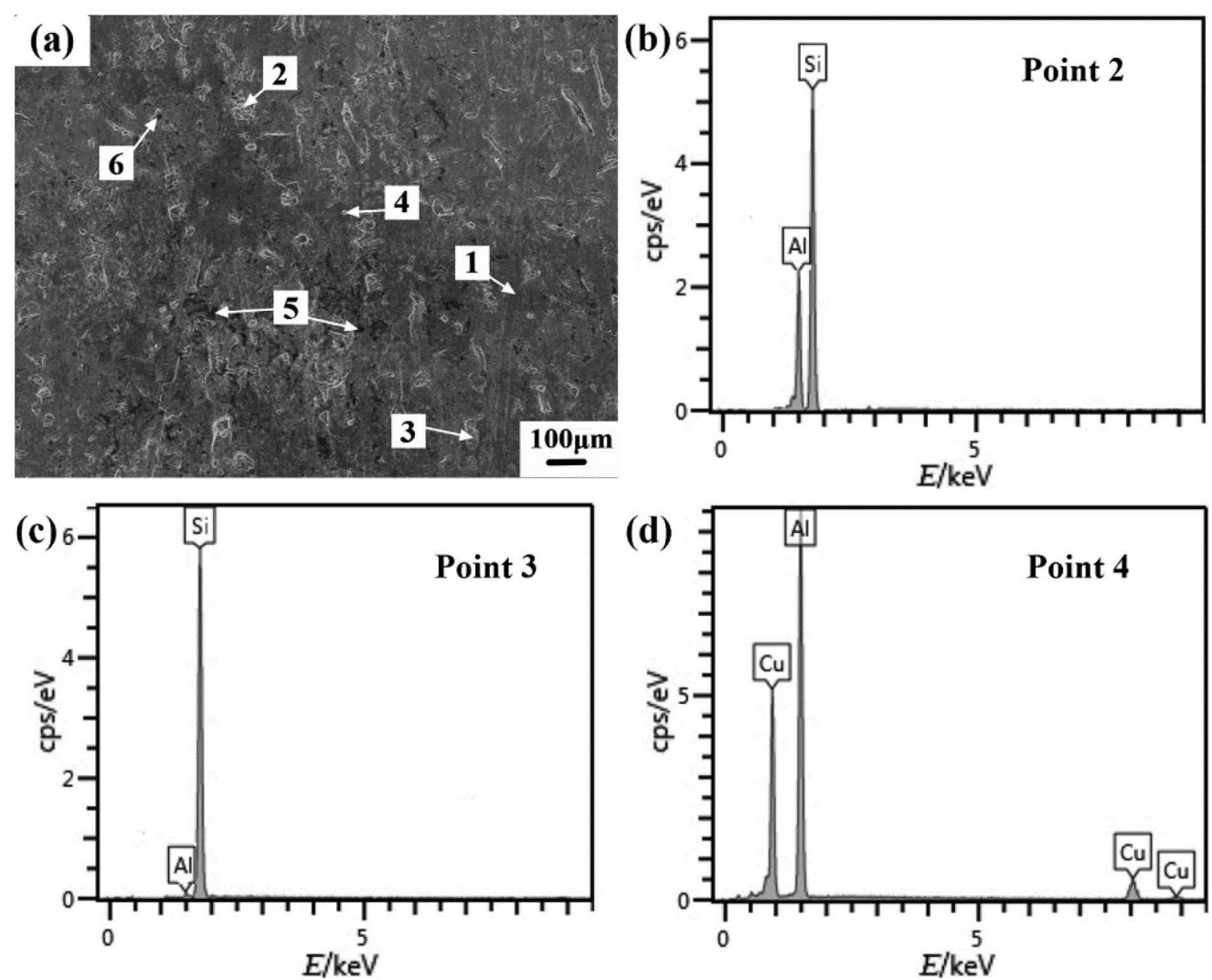

Figure 4: Microstructure with a suction diameter of $3 \mathrm{~mm}$ and EDS results: a) microstructure: 1 - (Al) matrix, 2 - eutectic Si, 3 - primary Si, 4 $\theta\left(\mathrm{Al}_{2} \mathrm{Cu}\right)$ phase, 5 - microporous area, 6 - insoluble impurity, b) (Al) $+\mathrm{Si}$ eutectic structure, c) primary $\mathrm{Si}$ phase, d) $\theta\left(\mathrm{Al}{ }_{2} \mathrm{Cu}\right)$ phase 

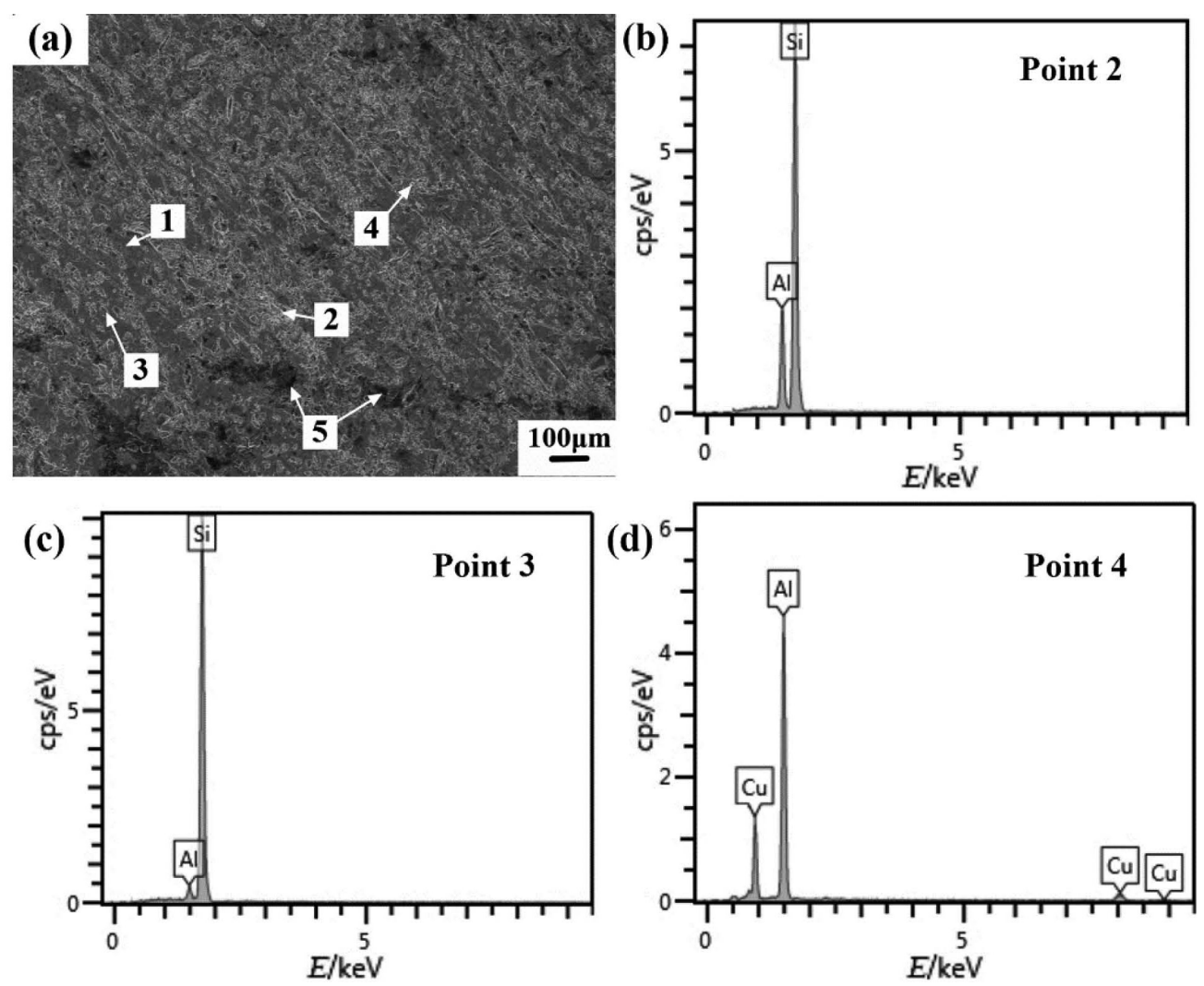

Figure 5: Microstructure with a suction diameter of $3.5 \mathrm{~mm}$ and EDS results: a) microstructure: 1 - (Al) matrix, 2 - eutectic $\mathrm{Si}, 3$ - primary $\mathrm{Si}$, $4-\theta\left(\mathrm{Al}_{2} \mathrm{Cu}\right)$ phase, 5 - microporous, b) $(\mathrm{Al})+\mathrm{Si}$ eutectic structure, c) primary Si phase, d) $\theta\left(\mathrm{Al}_{2} \mathrm{Cu}\right) \mathrm{phase}$

in the dendritic gap. These features also break the continuity of the matrix.

The polygonal primary $\mathrm{Si}$ flake content and the black-bulk microporosity decreased, as shown in Figure 4. The amount of eutectic Si increased and its distribution was uniform, which improved the mechanical properties. Some coarse rods or flakes appeared as bright white $\theta\left(\mathrm{Al}_{2} \mathrm{Cu}\right)$ phases as well as local fine-dot microvoids. A continuous matrix and weakened bonding between grains lowers the mechanical properties of the material. ${ }^{20}$

Some areas have concentrations of micropores in the matrix, as shown in Figure 5. These features increase the microporous area, which affects the mechanical properties and corrosion resistance of the castings. Further-

Table 4: Results of EDS component analysis ( $w / \%)$

\begin{tabular}{|c|c|c|c|c|c|}
\hline Test points & $\mathrm{Al}$ & $\mathrm{Si}$ & $\mathrm{Cu}$ & $\mathrm{Mg}$ & $\mathrm{Ti}$ \\
\hline Figure 3-1 & 89.69 & 9.89 & - & 0.41 & - \\
\hline Figure 3-2 & 44.36 & 55.64 & - & - & - \\
\hline Figure 3-3 & 3.39 & 96.61 & - & - & - \\
\hline Figure 4-2 & 37.34 & 62.66 & - & - & - \\
\hline Figure 4-3 & 2.60 & 97.40 & - & - & - \\
\hline Figure 4-4 & 57.26 & - & 42.74 & - & - \\
\hline Figure 5-2 & 10.34 & 89.66 & - & - & - \\
\hline Figure 5-3 & 4.60 & 95.40 & - & - & - \\
\hline Figure 5-4 & 71.40 & - & 28.60 & - & - \\
\hline
\end{tabular}

more, the content of polygonal primary Si flakes increased and their distribution became more disordered. The dendritic orientation of the matrix was irregular, which is disadvantageous in terms of casting properties.

\subsection{Effect of the suction-hole diameter on mechanical properties}

Figure 6 shows the mechanical properties of the castings under a negative differential pressure of $0.05 \mathrm{MPa}$ and different suction diameters $(2.5 \mathrm{~mm}, 3 \mathrm{~mm}$, and $3.5 \mathrm{~mm}$ ). The tension strength and microhardness of the castings first increased and then decreased as the suction diameter increased, as shown in Figure 6a. The elongation at break decreased at first and then increased, as shown in Figure 6b; however, the difference was not notable. When the suction diameter was $3 \mathrm{~mm}$, the tensile strength reached its highest level of $186.6 \mathrm{MPa}$, which accounted for $136.5 \%$ and $110.7 \%$ of the values for the $2.5-\mathrm{mm}$ and $3.5-\mathrm{mm}$ suction holes, respectively. The elongation at break of the 3-mm-diameter sample was $16.161 \%$, as shown in Figure 6a. The microhardness of this sample was the highest at $98.6 \mathrm{HV}$, which accounted for $146.8 \%$ and $110.6 \%$ of the values for the $2.5-\mathrm{mm}$ and 3.5-mm suction holes, respectively. Figure $6 \mathbf{c}$ shows the stress/strain curves of the castings with different suction diameters. The yield points of the castings were not clear, owing to the existence of micropores of different 

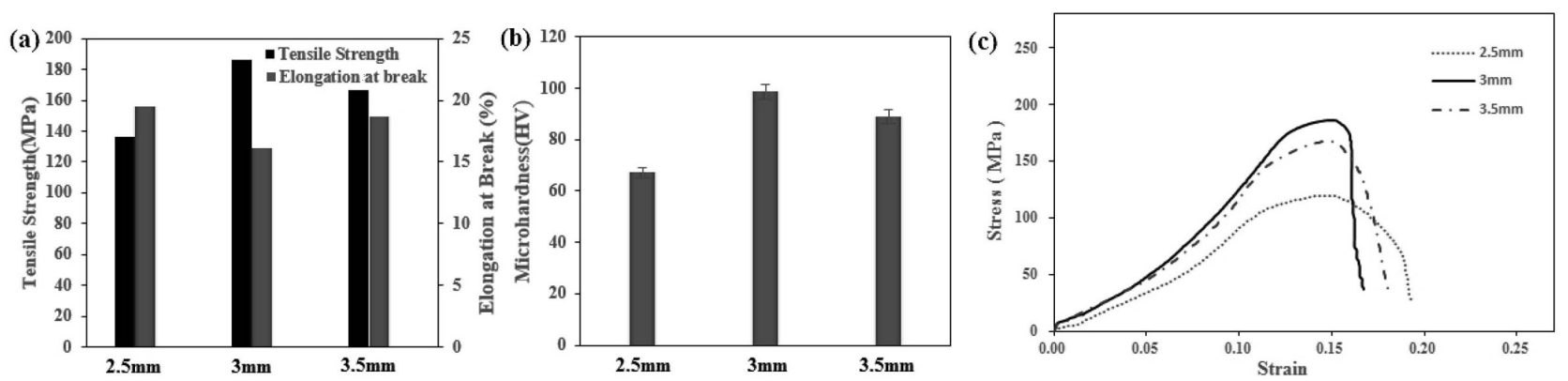

Figure 6: Mechanical properties of castings with different suction-hole diameters: a) tensile strength and elongation at break, b) microhardness, c) stress/strain curve

sizes in the castings, which greatly influenced the tensile properties of the castings.

Comparing the microstructure and EDS analysis results from Figure 3, it can be observed that a large amount of microporous and granular insoluble slag was distributed irregularly in the matrix of the samples, as shown in Figure 3. These defects degraded the mechanical properties of the material, causing the tensile strength and microhardness to be notably lower than for the samples formed with the suction diameters of $3 \mathrm{~mm}$ and 3.5 $\mathrm{mm}$. In addition, the content of primary Si flakes was also high and the mechanical properties were affected by the cleavage of the matrix structure in Figure 3.

When the suction diameter was $3 \mathrm{~mm}$, as shown in Figure 4, the eutectic structure of $\alpha(\mathrm{Al})+\mathrm{Si}$ was uni- form, and the fine microstructure improved the strength and plasticity of the alloy. ${ }^{19,21}$ Furthermore, a certain amount of microporosity was retained, as shown in Figure 4. This weakened the strength and brittleness of the alloy. However, as loose holes were small and scattered in different places, its overall performance was much better than that of the sample formed at the suction diameter of $2.5 \mathrm{~mm}$.

For the samples formed at the suction diameter of $3.5 \mathrm{~mm}$, the distribution of the eutectic Si structure was irregular, and primary Si flakes were present, as shown in Figure 5. These features are not conducive to improving the alloy properties. However, there was a small proportion of the insoluble $\theta\left(\mathrm{Al}_{2} \mathrm{Cu}\right)$ phase because it was soluble in the matrix. The existence of large local pores,
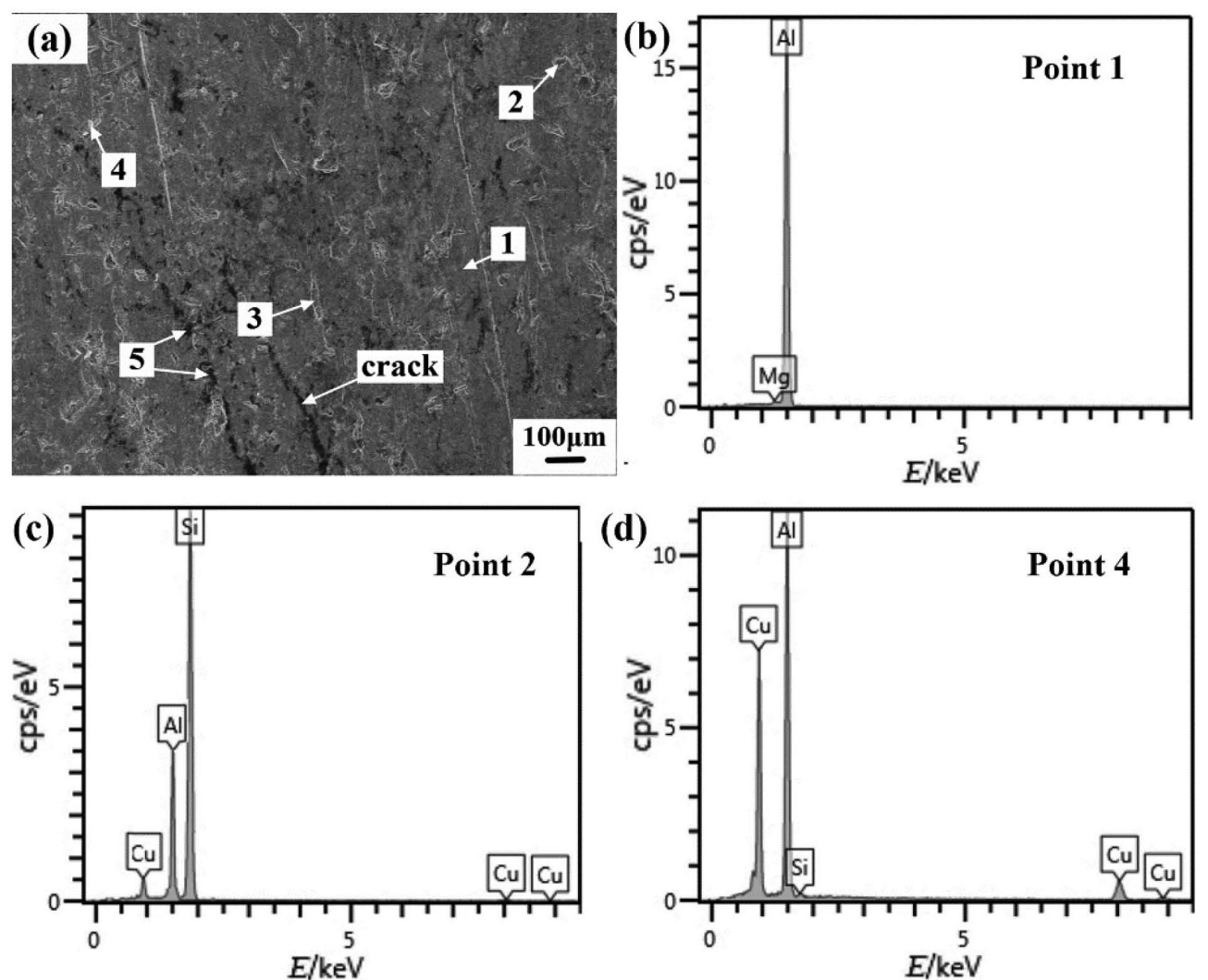

Figure 7: Microstructure with the differential pressure of $0.02 \mathrm{MPa}$ and EDS results: a) microstructure: 1 - (Al) matrix, 2 - eutectic Si, 3 - primary $\mathrm{Si}, 4-\theta\left(\mathrm{Al}_{2} \mathrm{Cu}\right), 5-$ micropores, b) $(\mathrm{Al})$ matrix, c) $(\mathrm{Al})+\mathrm{Si}$ eutectic structure, d) $\theta\left(\mathrm{Al}_{2} \mathrm{Cu}\right.$ phase $)$ 
an aggregation of microvoids and insoluble impurities deteriorated the performance. Therefore, the performance of the 3.5-mm-diameter sample was slightly poorer than that of the 3-mm sample, but it was better than that of the $2.5-\mathrm{mm}$ sample.

\subsection{Effect of the negative differential pressure on the microstructure}

Figures 7 and $\mathbf{8}$ show the microstructure and EDS analysis results of the castings formed with a suction diameter of $3 \mathrm{~mm}$ and negative differential pressures of $0.02 \mathrm{MPa}$ and $0.08 \mathrm{MPa}$, respectively. The results for the suction diameter of $3 \mathrm{~mm}$ and negative-pressure difference of $0.05 \mathrm{MPa}$ refer to the microstructure and EDS analysis from Figure 4. The values included in Figures 7 and 8 were consistent with those in Table 3. Table 5 shows the mass fractions of elements for each EDS test point from Figures $\mathbf{7}$ and $\mathbf{8}$.

Table 5: Results of EDS component analysis ( $w / \%)$

\begin{tabular}{|c|c|c|c|c|c|}
\hline Test point & $\mathrm{Al}$ & $\mathrm{Si}$ & $\mathrm{Cu}$ & $\mathrm{Mg}$ & $\mathrm{Ti}$ \\
\hline Figure 7 - 1 & 99.52 & - & - & 0.48 & - \\
\hline Figure 7 - 2 & 28.52 & 68.49 & 2.99 & - & - \\
\hline Figure 7 - 4 & 57.48 & 0.44 & 42.07 & - & - \\
\hline Figure 8 - 1 & 94.59 & - & - & 0.54 & 4.86 \\
\hline Figure 8 - 2 & 18.35 & 79.28 & 2.37 & - & - \\
\hline Figure 8 - 3 & 4.52 & 95.48 & - & - & - \\
\hline
\end{tabular}
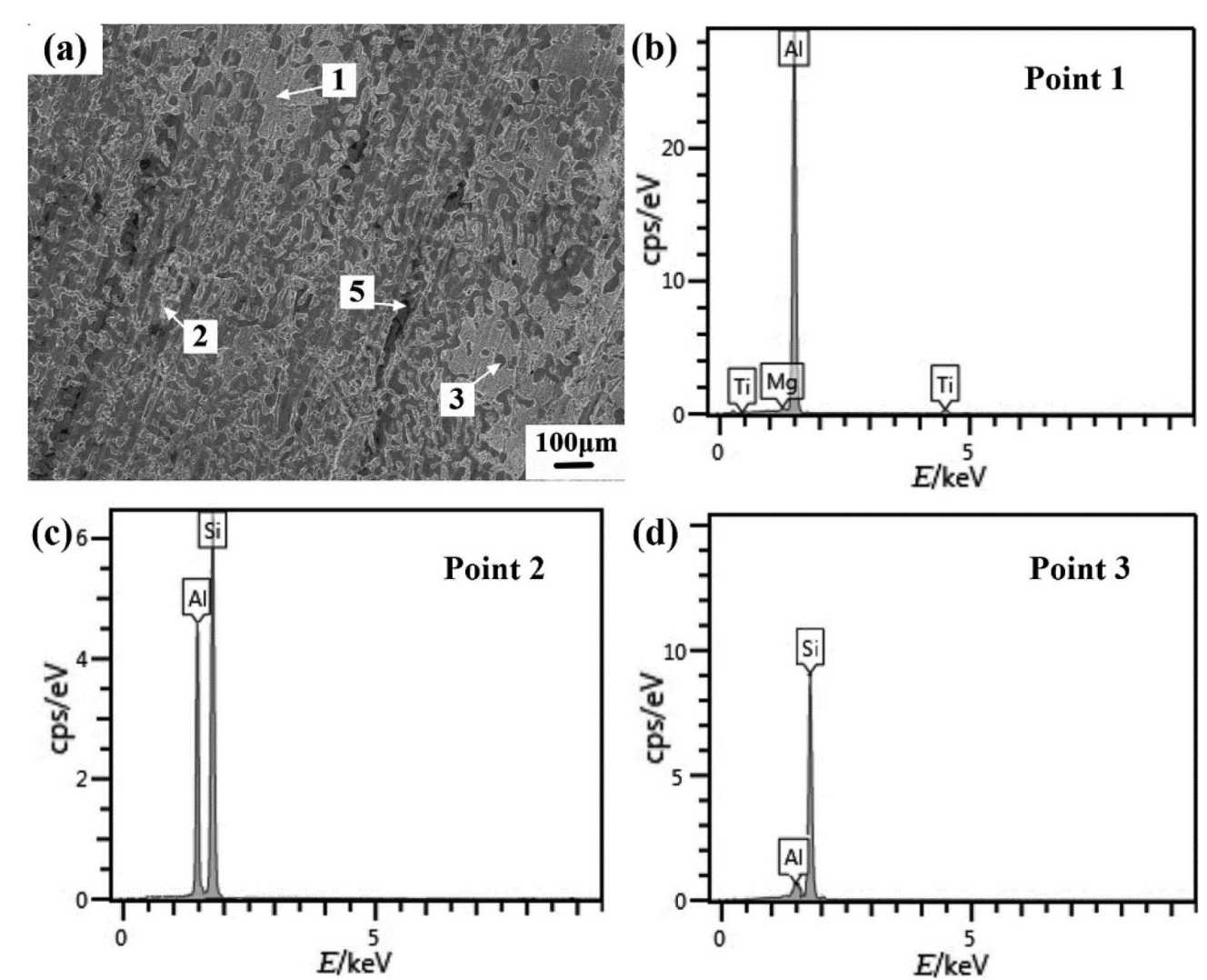

Comparing Figures 4, $\mathbf{7}$ and $\mathbf{8}$, we find that as the negative differential pressure increased, the microporosity tended to decrease. When the negative differential pressures were $0.02 \mathrm{MPa}$ and $0.05 \mathrm{MPa}$, the samples had a higher content of the rod-shaped bright white $\theta\left(\mathrm{Al}_{2} \mathrm{Cu}\right)$ phase than the sample formed at $0.08 \mathrm{MPa}$. The $\theta$ $\left(\mathrm{Al}_{2} \mathrm{Cu}\right)$ phase was mainly dissolved in the matrix, forming a solid solution at $0.08 \mathrm{MPa}$, as shown in Figure 8 . In addition, two longitudinal cracks appeared when the negative differential pressure was $0.02 \mathrm{MPa}$, as shown in Figure 7. This effect causes serious microdamage to the castings.

Furthermore, Figure 7 shows the primary Si phase, causing the cleavage of the matrix continuity and affecting the properties of the material to some extent. Furthermore, there are two large longitudinal cracks and black blocks of microporosity, which reduced the continuity of the microstructure and adversely affected the mechanical properties and corrosion resistance of the material.

In Figure 4, although there are no obvious cracks, the primary Si flake content is high, which is not conducive to improving the alloy properties. In addition, there is slight but widespread shrinkage in the center and lower left side, which reduced the performance of the castings. In Figure 8, the primary $\mathrm{Si}$ is uniformly distributed and its orientation is regular. The bright white $\theta\left(\mathrm{Al}_{2} \mathrm{Cu}\right)$ phase is almost invisible. This structure suggests an improvement in the strength of grain boundaries; however,

Figure 8: Microstructure with the differential pressure of $0.08 \mathrm{MPa}$ and EDS results: a) microstructure: 1 - (Al) matrix, 2 - eutectic Si, 3 - primary $\mathrm{Si}, 4-\theta\left(\mathrm{Al}_{2} \mathrm{Cu}\right), 5$ - micropores, b) (Al) matrix, c) eutectic Si phase, d) primary Si phase 

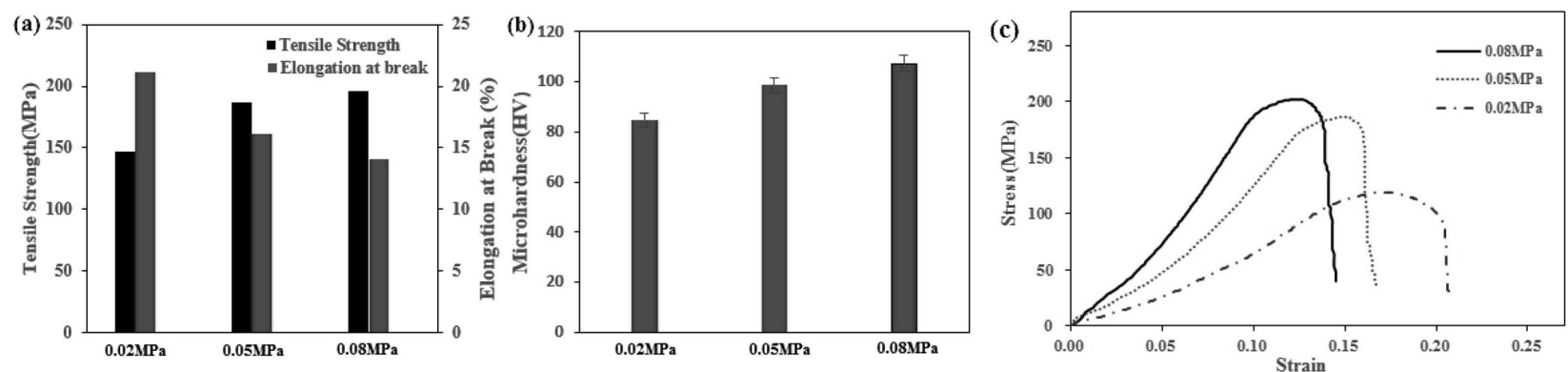

Figure 9: Mechanical properties of castings under different negative differential pressures: a) tensile strength and elongation at break, b) microhardness, c) stress/strain curve

some impurities and microvoids remained in the microstructure.

\subsection{Effect of the negative differential pressure on me- chanical properties}

Figure 9 shows the mechanical properties of the castings under the suction diameter of $3 \mathrm{~mm}$ and negative differential pressures of $(0.02,0.05$, and 0.08$) \mathrm{MPa}$. The figures show that as the negative differential pressure increased, the tension strength of the castings increased, the elongation at break decreased, and the microhardness gradually increased. When the negative differential pressure was $0.08 \mathrm{MPa}$, the tension strength reached its highest level, i.e., $195.8 \mathrm{MPa}$, accounting for $133.7 \%$ and $104.9 \%$ of the values for the samples formed at $(0.02$ and 0.05$) \mathrm{MPa}$, respectively. The elongation at break of the sample formed at $0.08 \mathrm{MPa}$ was $14.0 \%$, and this sample had the highest microhardness, i.e., $107.3 \mathrm{HV}$, accounting for $126.6 \%$ and $108.8 \%$ of the values for the samples formed at $(0.02$ and 0.05$) \mathrm{MPa}$, respectively. Figure 6c shows the stress/strain curves of the castings under different negative pressures. The maximum stress gradually increased as the negative pressure difference increased; however, the maximum strain showed the opposite trend. We attribute this result to the absence of an obvious yield point in the microporous defects of the castings.

Comparing the microstructures from Figures $\mathbf{7}$ and $\mathbf{8}$, we can observe that some polygonal lamellar primary $\mathrm{Si}$ is irregularly distributed in the matrix in Figure 7, and this coarse structure has a negative effect on the continuity of the matrix, lowering its properties. In addition, more insoluble $\theta\left(\mathrm{Al}_{2} \mathrm{Cu}\right)$ phases are present. It is shown that a certain amount of the $\theta\left(\mathrm{Al}_{2} \mathrm{Cu}\right)$ phase is distributed in the grain gap, which is conducive to hindering lattice defects. ${ }^{22,23}$ However, an excessive distribution of the coarse $\theta\left(\mathrm{Al}_{2} \mathrm{Cu}\right)$ phase at grain boundaries decreases the grain boundary and material strength. The plasticity of the material is reduced accordingly because of the increased proportion of the strengthening phase. ${ }^{24}$ As shown in Figure 7, two longitudinal cracks and some microporosity caused deterioration of both the strength and hardness, ${ }^{25}$ hence, the performance was poorer than that of the sample formed at $0.08 \mathrm{MPa}$. When the nega- tive differential pressure was $0.08 \mathrm{MPa}$, no apparent granular insoluble impurities or $\theta\left(\mathrm{Al}_{2} \mathrm{Cu}\right)$ phases were found in the matrix, as shown in Figure 8. Hence, the overall performance was better than that of the sample grown at $0.02 \mathrm{MPa}$.

Comparing the microstructures from Figures $\mathbf{4}$ and $\mathbf{8}$, we can conclude that some primary $\mathrm{Si}$ flakes were irregularly distributed in the matrix, as shown in Figure 4. The major effects on the mechanical performance are attributed to the existence of microporosity. Figure 8 shows that although some microporous features were present, their number and distribution range were limited so that the strength and hardness were slightly better than those of the sample formed under a negative differential pressure of $0.05 \mathrm{MPa}$.

\section{CONCLUSIONS}

1) When the suction-hole diameter was increased, the microporosity decreased at first and then increased, making the distribution of the eutectic Si more uniform and then chaotic, respectively. When the suction diameter was $2.5 \mathrm{~mm}$, the microscopic looseness of the samples was considerably higher than for the samples formed at diameters of $3 \mathrm{~mm}$ and $3.5 \mathrm{~mm}$. Furthermore, when the suction diameter was $3 \mathrm{~mm}$, the distribution of the eutectic Si was most uniform.

2) As the negative differential pressure was increased, the content of primary Si flakes in the structure decreased, and the eutectic structure of $\alpha(\mathrm{Al})+\mathrm{Si}$ became more uniform and better oriented. The apparent shrinkage and looseness gradually decreased, but two longitudinal cracks appeared in the structure when the pressure differential was $0.02 \mathrm{MPa}$.

3) As the negative differential pressure increased, the tensile strength and microhardness of the specimens gradually improved. When the suction-hole diameter was increased, the tension strength and microhardness first increased and then decreased. For the suction-hole diameter of $3 \mathrm{~mm}$ and negative pressure differential of 0.08 $\mathrm{MPa}$, the tension strength and microhardness of the casting reached their maximum values. The tension strength of this sample was $195.8 \mathrm{MPa}$, its elongation at break was $14.093 \%$ and its microhardness was $107.3 \mathrm{HV}$. 


\section{Acknowledgements}

This project was funded by the Shanghai Committee of Science and Technology (Grant No. 16030501200) and National Natural Science Foundation of China (Grant No. 51805314). The Robot Functional Materials Preparation Laboratory of the Shanghai University of Engineering Science is also gratefully acknowledged.

\section{REFERENCES}

${ }^{1}$ H. Toda, T. Nishimura, K. Uesugi, Y. Suzuki, M. Kobayashi, Influence of high-temperature solution treatments on mechanical properties of an Al-Si-Cu aluminum alloy, Acta Materialia, 58 (2010), 2014-2025, doi:10.1016/j.actamat.2009.11.044

${ }^{2}$ G. Y. Lin, Y. X. Lei, D. Q. Guo, X. Z. Xu, Z. P. Zhang, Heat treatment strengthening and microstructure characteristics of wrought Al-Si-Cu-Mg alloy, Chinese Journal of Nonferrous Metals, 24 (2014), 584-592, doi:10.1007/s11015-014-9858-6

${ }^{3}$ I. Bacaicoa, M. Wicke, M. Luetje, F. Zeismann, A. Brueckner-Foit, A. Geisert, M. Fehlbier, Characterization of casting defects in a Fe-rich Al-Si-Cu alloy by microtomography and finite element analysis, Engineering Fracture Mechanics, $183 \quad$ (2017), doi:10.1016/j.engfracmech.2017.03.015

${ }^{4}$ C. Padmavathi, A. Upadhyaya, Sintering behaviour and mechanical properties of $\mathrm{Al}-\mathrm{Cu}-\mathrm{Mg}-\mathrm{Si}-\mathrm{Sn}$ aluminum alloy, Transactions of the Indian Institute of Metals, 64 (2011), 345-357, doi:10.1007/ s12666-011-0089-2

${ }^{5}$ E. H. Kim, G. H. Cho, Y. S. Oh, Y. G. Junga, Development of a high-temperature mold process for sand casting with a thin wall and complex shape, Thin Solid Films, 620 (2016), 70-75, doi:10.1016/ j.tsf.2016.08.069

${ }^{6}$ J. Pan, R. Hong, J. Wang, Production of complex thin-walled aluminum alloy castings by counter-gravity casting, Special Casting \& Nonferrous Alloys, 30 (2012), 244-245, doi:10.15980/j.tzzz.2012. 10.010

${ }^{7}$ P. Tingting, H. Tao, H. Yuanming, X. Shi, S. Chen, K. Yu, A. Sun, Effect of process parameters on microstructure and properties of ZL116 aluminum alloy after vacuum suction cast, Mater. Tehnol., 52 (2018), 795-801, doi:10.17222/mit.2018.094

${ }^{8}$ T. He, H. J. Liu, X. J. Shi, Y. M. Huo, L. Min, T. T. Pan, Effect of Si and $\mathrm{Mn}$ on microstructure and mechanical properties of vacuum suction casting Al-4.5Cu alloy, Strength of Materials, 50 (2018), doi:10.1007/s11223-018-0011-9

${ }^{9}$ Y. Su, W. Liu, L. Luo, X. Ye, J. Guo, H. Fu, Research on forming process of TA15 alloy impeller by bottom vacuum suction casting technology, Rare Metal Materials and Engineering, 41 (2012), 115-119, doi:10.1088/1757-899X/27/1/012043

${ }^{10}$ X. C. Ye, W. G. Zhao, The study on TiAl based alloy blade casting structure by bottom pouring vacuum suction casting, Applied Mechanics and Materials, 442 (2014), 44-47, doi:10.4028/www.scientific.net/amm.442.44

${ }^{11}$ S. Samal, S. Agarwal, K. Biswas, Phase evolution and mechanical properties of suction cast $\mathrm{Ti}-\mathrm{Fe}-\mathrm{Co}$ ternary alloys, Transactions of the Indian Institute of Metals, 71 (2018), 201-207, doi:10.1007/ s12666-017-1174-y

${ }^{12}$ N. Das, P. Sengupta, G. Abraham, A. Arya, V. Kain, G. K. Dey, Development in corrosion resistance by microstructural refinement in
Zr-16 SS 304 alloy using suction casting technique, Materials Research Bulletin, 80 (2016), 295-302, doi:10.1016/j.apsusc.2007. 10.013

${ }^{13}$ T. Ito, M. Noda, H. Mori, Effect of antigravity-suction-casting parameters on microstructure and mechanical properties of Mg-10Al-0.2Mn-1Ca cast alloy (Special Issue on Platform Science and Technology for Advanced Magnesium Alloys(6)), Materials Transactions, 55 (2014), 1184-1189, doi:10.2320/matertrans. MC201401

${ }^{14}$ S. Kashiwai, I. Ohnaka, A. Kimatsuka, T. Kaneyoshi, T. Ohmichi, J. Zhu, Numerical simulation and X-ray direct observation of mould filling during vacuum suction casting, Cast Metals, 18 (2013), 144-148, doi:10.1179/136404605225023027

${ }^{15}$ A. K. Mishra, S. Samal, K. Biswas, Solidification behaviour of $\mathrm{Ti}-\mathrm{Cu}-\mathrm{Fe}-\mathrm{Co}-\mathrm{Ni}$ high entropy alloys, Transactions of the Indian Institute of Metals, 65 (2012), 725-730, doi:10.1007/s12666-0120206-X

${ }^{16}$ I. Outmani, L. Fouilland-Paille, J. Isselin, M. El Mansori, Effect of $\mathrm{Si}, \mathrm{Cu}$ and processing parameters on $\mathrm{Al}-\mathrm{Si}-\mathrm{Cu} \mathrm{HPDC}$ castings, Journal of Materials Processing Technology, 249 (2017), 559-569, doi:10.1016/j.jmatprotec.2017.06.043

${ }^{17}$ S. Wang, Y. Tang, Q. Yang, J. H. Cho, Particles morphology and forming analysis of Al-Si-Cu-Mg alloys, Journal of Harbin Institute of Technology, 22 (2015), 85-91, doi:10.11916/j.issn.10059113.2015.06.012

${ }^{18}$ M. L. N. M. Melo, E. M. S. Rizzo, R. G. Santos, Predicting dendrite arm spacing and their effect on microporosity formation in directionally solidified Al-Cu alloy, Journal of Materials Science, 40 (2005), 1599-1609, doi:10.1007/s10853-005-0659-y

${ }^{19}$ F. Wang, Y. Zeng, B. Xiong, Y. Zhang, X. Li, Z. Li, H. Liu, Effect of $\mathrm{Si}$ addition on the microstructure and mechanical properties of $\mathrm{Al}-\mathrm{Cu}-\mathrm{Mg}$ alloy, Journal of Alloys and Compounds, 585 (2014), 474-478, doi:10.1016/j.jallcom.2013.08.214

${ }^{20}$ S. Sun, X. Peng, W. Xie, M. Yu, Influences of T6 heat treatment on microstructure and mechanical properties of A356 alloy modified by Al-Sr master alloy, Hot Working Technology, 39 (2010), 155-157, doi:10.14158/j.cnki.1001-3814.2010.18.042

${ }^{21}$ W. Zhang, J. Yang, Y. Liu, J. Dang, Effect of Si, Cu and Mg on mechanical properties of Al-Si-Cu-Mg alloy, Hot Working Technology, 41 (2012), 104-106, doi:10.14158/j.cnki.1001-3814.2012.22.067

${ }^{22}$ Z. Li, A. M. Samuel, F. H. Samuel, C. Ravindran, S. Valtierra, Effect of alloying elements on the segregation and dissolution of CuAl 2 phase in Al-Si-Cu 319 alloys, Journal of Materials Science, 38 (2003), 1203-1218, doi:10.1023/A:1022857703995

${ }^{23}$ S. G. Shabestari, H. Moemeni, Effect of copper and solidification conditions on the microstructure and mechanical properties of Al-Si-Mg alloys, Journal of Materials Processing Tech, 153-154 (2004), 193-198, doi:10.1016/j.jmatprotec.2004.04.302

${ }^{24}$ M. S. Salleh, M. Z. Omar, Influence of $\mathrm{Cu}$ content on microstructure and mechanical properties of thixoformed $\mathrm{Al}-\mathrm{Si}-\mathrm{Cu}-\mathrm{Mg}$ alloys, Transactions of Nonferrous Metals Society of China, 25 (2015), 3523-3538, doi:10.1016/S1003-6326(15)63995-4

${ }^{25}$ T. S. N. S. Narayanan, I. S. Park, H. L. Min, Strategies to improve the corrosion resistance of microarc oxidation (MAO) coated magnesium alloys for degradable implants: Prospects and challenges, Progress in Materials Science, 60 (2014), 1-71, doi:10.1016/j.pmatsci. 2013.08.002 